\title{
Diversity, Distribution and Composition of the Bivalvia Class on the Rocky Intertidal Zone of Marine Priority Region 32, Mexico
}

\author{
Rafael Flores-Garza1, Victor López-Rojas', Pedro Flores-Rodríguez" \\ Carmina Torreblanca Ramírez² \\ ${ }^{1}$ Unidad Académica de Ecología Marina, Universidad Autónoma de Guerrero, Acapulco, Mexico \\ ${ }^{2}$ Unidad de Ciencias de Desarrollo Regional, Universidad Autónoma de Guerrero, Acapulco, Mexico \\ Email: rfloresgarza@yahoo.com, vilopezrojas@yahoo.com
}

Received 3 October 2014; revised 28 October 2014; accepted 4 November 2014

Copyright (C) 2014 by authors and Scientific Research Publishing Inc.

This work is licensed under the Creative Commons Attribution International License (CC BY). http://creativecommons.org/licenses/by/4.0/

(c) (i) Open Access

\begin{abstract}
The Bivalvia Class, is widely represented in marine ecosystems and is economically important; this research focused on this class and was carried out by sampling the rocky intertidal zone of seven sites located in the Marina Region Priority No. 32, Guerrero, Mexico, where the National Commission for the Knowledge and Use of Biodiversity reported lack of knowledge on marine species living there. The objectives were to examine species richness associated with the rocky intertidal zone, determine how the community is composed by the representation of families based on species richness and abundance, know the distribution of the species, analyze the structure sizes of populations and estimate the diversity index. Sampling was conducted at seven sites; the sampling unit was one square meter and the sampling area was $10 \mathrm{~m}^{2} .32$ species were identified. Four species are new records for the Mexican Pacific Transitional: one for the state of Guerrero and one for Marine Priority Region 32. Arcidae and Mytilidae Families were better represented in species richness and Chamidae Family was the best represented in abundance. Chama coralloides was considered to be the representative species of the area; Striostrea prismatica showed the greatest size. The diversity index was estimated $\left(\mathrm{H}^{\prime}=3.65 \mathrm{bits} / \mathrm{individuals}\right)$. Species richness is high and corresponds to that expected in a tropical area.
\end{abstract}

\section{Keywords}

Bivalvia, Distribution, Intertidial Zone, Guerrero, Mexico

\section{Introduction}

North America has been divided into 24 marine ecoregions, seven of which are located in Mexico. The coast

How to cite this paper: Flores-Garza, R., López-Rojas, V., Flores-Rodríguez, P. and Torreblanca-Ramírez, C. (2014) Diversity, Distribution and Composition of the Bivalvia Class on the Rocky Intertidal Zone of Marine Priority Region 32, Mexico. Open Journal of Ecology, 4, 961-973. http://dx.doi.org/10.4236/oje.2014.415080 
state of Guerrero is located in marine ecoregion 17, also called Mexican Pacific Transitional. Besides the Guerrero coast in this ecoregion, the coasts of the states of Jalisco, Colima, Michoacán, Oaxaca and the southern tip of Baja California Sur are included. The physiography of this ecoregion is characterized by a narrow continental shelf with an amplitude of $10-15 \mathrm{~km}$ and a slope of less than $1^{\circ} 30^{\prime}$, with a deep ocean trench and complex abyssal plains [1].

The coast state of Guerrero has a length of $470 \mathrm{~km} \mathrm{[2]} \mathrm{and} \mathrm{has} \mathrm{different} \mathrm{habitat} \mathrm{types.} \mathrm{The} \mathrm{National} \mathrm{Commis-}$ sion for the Conservation and Use of Biodiversity (Comisión Nacionalpara la Conservación y Uso de la Biodiversidad, CONABIO) reports for the state of Guerrero four priority marine regions (30,31, 32, and 33) for the conservation and use of biodiversity (MPR) and reports that the knowledge of biodiversity in these regions is limited [3]. So it is important to conduct research that provides information about the diversity in the MPR, in addition to analyzing various aspects of ecological populations and communities of marine organisms.

The MPR 32 (Coyuca-Tres Palos) has an area of $829 \mathrm{~km}^{2}$. This region is classified as an area with high biodiversity and presents problems such as modification of the environment by discharges of fresh water, chemicals and fertilizers, damage to the environment due to tourist transport, the introduction of exotic species and the current lack of regulations regarding the use of natural resources [3]. This region has large rocky intertidal areas, which are located in Acapulco. This area is exposed to constant immersion and emersion and presents a variety of conditions in which life can develop.

Mollusks are a part of the marine fauna that make up the MPR 32, and within this taxon, are the Bivalvia Class. Members of this class are diverse, abundant, have commercial importance and are also an important part of fishery production [4].

There are few reports on the Bivalvia Class in the state of Guerrero, and these are primarily concerning commercially important species [5] [6]. There are reports of mollusks in research carried out in different sites of the Mexican Pacific coast, where the Class Bivalvia is included; these refer to the diversity, structure and variation in the community over time [7]-[14]. Other reports provide information on distribution and abundance [15]-[24].

For the rocky intertidal zone of the MPR 32, there are reports based on community studies of mollusks, where the Bivalvia Class is among the classes analyzed. These studies deal with species richness, diversity, abundance and the zonation of mollusks [25]-[34].

This research was focused on the organisms of the Bivalvia Class associated with the rocky intertidal zone of the MPR 32 and the objectives were: to determine the species richness, examine the composition of the community from the representation of families and analyze the relative abundance distribution and size composition of the species in the community.

\section{Methodology}

\subsection{Study Area}

The MPR 32 is located between the lagoons Coyuca and Tres Palos (Latitude $16^{\circ} 35^{\prime} 24^{\prime \prime} \mathrm{N}, 17^{\circ} 28^{\prime} 12^{\prime \prime} \mathrm{W}$ and Longitude $99^{\circ} 25^{\prime} 12^{\prime \prime} \mathrm{N}, 100^{\circ} 33^{\prime} \mathrm{W}$ ) [3]. Sampling was conducted at sevensites in therocky intertidal zone of the MPR 32 (Majahua, Tlacopanocha, Parque de la Reina, Muelle, La Angosta, Manzanillo y Pie de la Cuesta). Each location was geographically referenced and described according to the following criteria: length of the sampling area, type of substrate, types of rock, substrate stability and wave exposure. The descriptions of the collecting sites were based on [35] and maps produced by the National Institute of Statistics, Geography and Informatics (Insituto Nacional de Geografia, Estadistica e Informatica, INEGI) and were complemented with field observations (Table 1 and Figure 1).

These sites vary in type, substrate stability and wave exposure. Substrate types were classified as: 1) massif rocks: fixed structures such as walls, cliffs, terraces, etc., 2) blocks: loose rock larger than $50 \mathrm{~cm}$ in diameter, made of rocks that are submerged and immovable or difficult to move about by the impact of waves, 3) boulders: loose rock with a size of less than 50 and greater than $8 \mathrm{~cm}$ in diameter, rocks that can be easily moved by the impact of waves, 4) gravel: loose rock no more than $8 \mathrm{~cm}$ in diameter, 5) artificial substrate: concrete blocks or construction waste.

The stability of the substrate was classified as: 1) high: when the substrate remains virtually unchanged by the impact of waves, 2) middle: when the impact of the waves does not change the configuration of the substrate but there is rock movement, 3 ) low: when the site configuration is changed by the impact of waves, most of the 


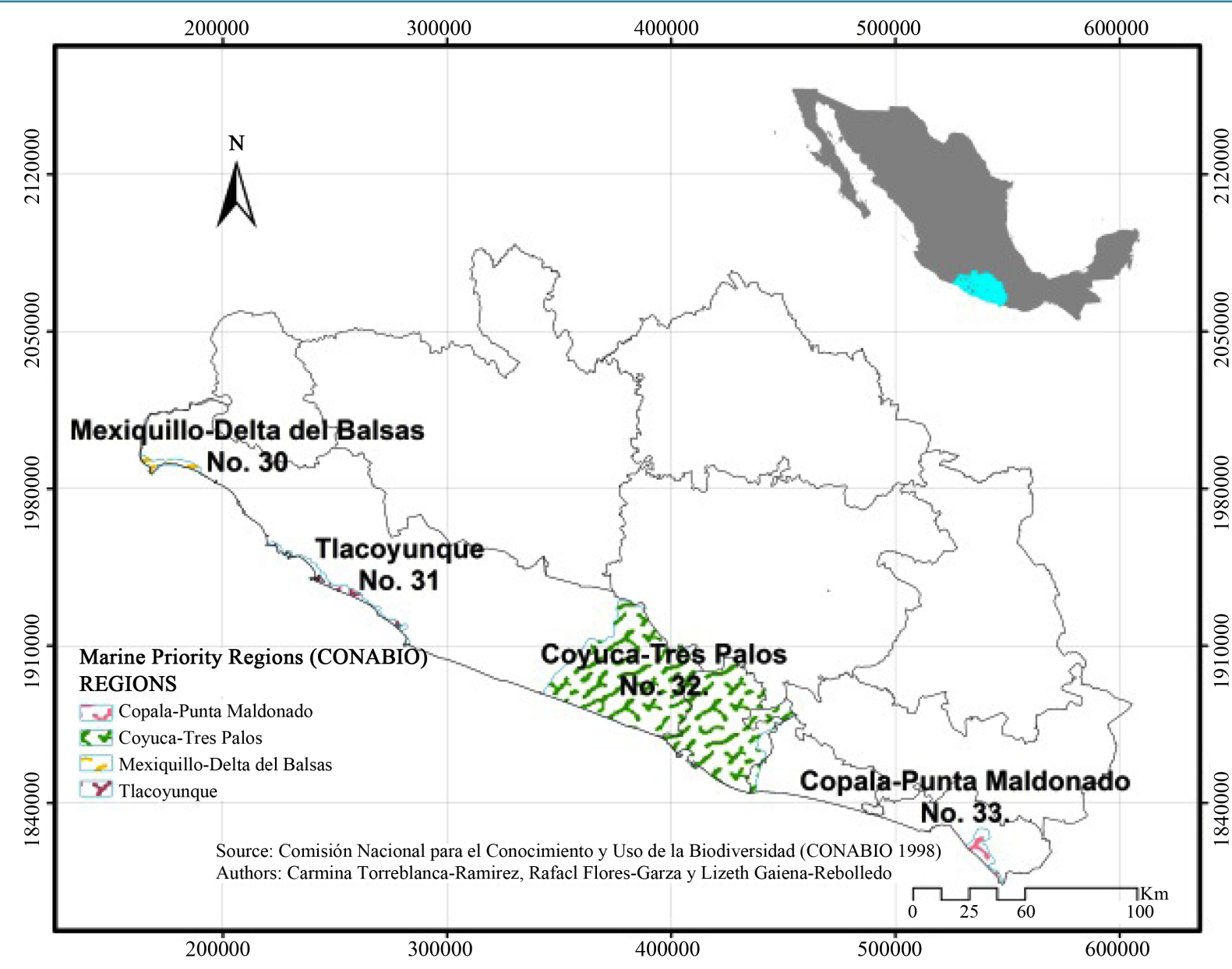

Figure 1. Marine priority regions at the state of Guerrero, México.

Table 1. Geographical location and the most relevant characteristics of the sampling sites.

\begin{tabular}{|c|c|c|c|c|c|c|c|c|}
\hline & \multirow{2}{*}{ Site } & \multicolumn{2}{|c|}{ Coordinates } & \multirow{2}{*}{$\begin{array}{l}\text { Length } \\
\text { (m) }\end{array}$} & \multirow{2}{*}{ Type of substrate } & \multirow{2}{*}{ Type of rock } & \multirow{2}{*}{$\begin{array}{l}\text { Substrate } \\
\text { stability }\end{array}$} & \multirow{2}{*}{$\begin{array}{l}\text { Wave } \\
\text { exposure }\end{array}$} \\
\hline & & Latitude & Longitude & & & & & \\
\hline 1 & Majahua & $16^{\circ} 47^{\prime} 40.49^{\prime \prime}$ & $99^{\circ} 50 ' 30.29^{\prime \prime}$ & 600 & Blocks and boulders & Metamorphic & High & Low \\
\hline 2 & Tlacopanocha & $16^{\circ} 50^{\prime} 41.53^{\prime \prime}$ & $99^{\circ} 54^{\prime} 25.02 "$ & 200 & Blocks and gravel & $\begin{array}{l}\text { Artificial substrate } \\
\text { and igneous }\end{array}$ & Middle & Middle \\
\hline 3 & $\begin{array}{l}\text { Parque de } \\
\text { la Reina }\end{array}$ & $16^{\circ} 51^{\prime} 2.27^{\prime \prime}$ & $99^{\circ} 54^{\prime} 01.70^{\prime \prime}$ & 66.74 & Boulders and gravel & $\begin{array}{l}\text { Artificial substrate } \\
\text { and igneous }\end{array}$ & Low & Middle \\
\hline 4 & Muelle & $16^{\circ} 50^{\prime} 56.86^{\prime \prime}$ & $99^{\circ} 54^{\prime} 02.39^{\prime \prime}$ & 60 & Blocks and boulders & $\begin{array}{l}\text { Metamorphic and } \\
\text { artificial substrate }\end{array}$ & Middle & Middle \\
\hline 5 & La Angosta & $16^{\circ} 60^{\prime} 29.86^{\prime \prime}$ & $99^{\circ} 54^{\prime} 55.70^{\prime \prime}$ & 48.14 & Massif rock and boulders & Metamorphic & High & High \\
\hline 6 & Manzanillo & $16^{\circ} 50^{\prime} 27.90^{\prime \prime}$ & $99^{\circ} 54^{\prime} 38.14^{\prime \prime}$ & 22.87 & Boulders and gravel & $\begin{array}{l}\text { Metamorphic } \\
\text { and artificial substrate }\end{array}$ & Low & Low \\
\hline 7 & $\begin{array}{l}\text { Pie de la } \\
\text { Cuesta }\end{array}$ & $16^{\circ} 52^{\prime} 25.64^{\prime \prime}$ & $99^{\circ} 56 ' 34.64^{\prime \prime}$ & 66 & Massif rock and boulders & Metamorphic & High & High \\
\hline
\end{tabular}

rocks are moved.

The wave exposure was classified as: 1) high: when the wave hits the substrate in a free manner, usually the sites that have this type of waves are outside of the protection of barriers such as bays or hooks, 2) middle: when the impact of the wave on the substrate is hindered by barriers or smoothing, as can occur at sites that are in front of the entrance of bays or at a distance from a wall of hooks, it also happens in places where subtidal rocky 
substrate emerges or is shallow and reduces the direct impact of the waves to the substrate, 3) low: when the wave does not directly hit the substrate, since the sites are protected by different types of barriers [36].

\subsection{Collection of Samples}

Three samplings were conducted per site between 2009 and 2012. Each sampling was performed during the hours of low tide and new moon days, the sampling area was $10 \mathrm{~m}^{2}$ and sampling unit was $1 \mathrm{~m}^{2}$. Sampling was systematic. The starting point of the sample was randomly selected in the rocky intertidal zone and the sampling unit was delimited using a $1 \mathrm{~m}^{2}$ frame made of PVC pipe. A rope $30 \mathrm{~m}$ in length, was placed next to the PVC frame, which extended parallel to the coast over the rocky intertidal zone, in order to define the transect on which sampling would be carried out.

All bivalve specimens found alive within the sampling unit, were collected and placed into a plastic container filled with seawater and protected from direct sunlight. The following sampling unit was placed along the transect two meters from the first sampling unit. This procedure was repeated to complete $10 \mathrm{~m}^{2}$. The specimens were placed in bottles containing $96 \%$ ethyl alcohol and taken to the laboratory to be identified and quantified.

\subsection{Laboratory Work and Data Analysis}

The identification of specimens and the update of the nomenclature, required confirmation in the laboratory, using literature such as [37]-[39].

The collected specimens were measured in length and width (mm). Species richness was assessed based on the number of species found in the samples. The community composition was analyzed using the representation of families, which was evaluated based on species richness and abundance of organisms per family and expressed as percentage. Relative abundance was measured as the percentage of each species with respect to the total number of specimens. The geographical distribution was evaluated using on the frequency of occurrence of species per site as follows: broad (frequency of 6 to 7 sites), regular (frequency of 3 to 5 sites) and limited (frequency of 1 to 2 sites).

The composition analysis of the sizes of the populations of bivalve was considered by measuring the length and width, and obtaining the descriptive statistical values such as maximum, minimum, mean and standard deviation for the species whose abundances were higher than 2 specimens. The diversity was measured using the Shannon-Wiener index $\left(\mathrm{H}^{\prime}\right)$ and Pielou index $\left(\mathrm{J}^{\prime}\right)$.

\section{Results}

1178 specimens were examined and found to that the Bivalvia Class associated with the rocky intertidal zone of MPR 32, is composed of 12 families, 21 genera and 32 species. The Mytilidae Family was the best represented in species richness, representing seven genera and eight species, followed by the Arcidae Family making up three genera and seven species. The site with the highest species richness was Manzanillo, which represented 78\% of the total bivalve species associated with rocky intertidal zone of the MRP 32. Tlacopanocha ranked second in species richness representing 50\%. Sites with lower species richness were Parque de la Reina and Pie de la Cuesta (Table 2).

Barbatia illota (Sowerby, 1833), Modiolus tumbezensis (Pilsbry \& Olsson, 1935), Ctena clarionensis (Hertlein \& Strong, 1946) and Martesia (Martesia) striata (Linnaeus, 1758) were identified as new records for the Mexican Pacific Transitional. Cardites laticostatus (Sowerby, 1833), was a new record for the state of Guerrero and Barbatia (C.) reeveana (d'Orbigny, 1846) a new record for the MRP 32 (Figure 2).

In relative abundance, Chamidae Family was the best represented with $35.82 \%$ of the total abundance, followed by the Family Mytilidae with $22.41 \%$. These two families were found in all sampling sites. Family Arcidae found at six sites, only in Pie de la Cuesta was not found. Species with wide distribution in the study area were registered in Mytilidae, Chamidae and Carditidae Families.

The Families Lucinidae, Pholadidae, Anomiidae and Pteridae are each represented by one species, were presented in one site and only one or two specimens were collected.

The highest relative abundance per site was recorded in Majahua (25.63\%) followed by Pie de la Cuesta (23.34\%). Both sites they accounted for just under 50\%. Parque de la Reina had the lowest value in relative abundance (2.46\%), followed by La Angosta (6.02\%). 
Table 2. Species richness, abundance and distribution of bivalve associated with the rocky intertidal zone at the MPR 32, Acapulco, Mexico.

\begin{tabular}{|c|c|c|c|c|c|c|c|c|c|}
\hline \multirow{2}{*}{ Families (RA)/species } & \multirow{2}{*}{$\mathrm{N}$} & \multicolumn{7}{|c|}{ Sites } & \multirow{2}{*}{$\mathrm{dt}$} \\
\hline & & A & $\mathrm{B}$ & $\mathrm{C}$ & $\mathrm{D}$ & E & $\mathrm{F}$ & G & \\
\hline \multicolumn{10}{|l|}{ MYTILIDAE (22.41\%) } \\
\hline Brachidontes adamsianus (Dunker, 1857) & 21 & 2 & 4 & 2 & 1 & 6 & 2 & 4 & $\mathrm{~W}$ \\
\hline Brachidontes puntarenensis (Pilsbry \& Olsson, 1935) & 21 & & & 4 & 3 & 6 & & 8 & $\mathrm{RE}$ \\
\hline Brachidontes semilaevis (Menke, 1848) & 2 & & & & & 2 & & & $\mathrm{~L}$ \\
\hline Septifer zeteki (Hertlein \& Strong, 1946) & 2 & & 2 & & & & & & $\mathrm{~L}$ \\
\hline Choromytilus palliopunctatus (Carpenter, 1857) & 151 & & & & & & & 151 & $\mathrm{~L}$ \\
\hline Lithophaga (Myoforceps) aristata (Dillwyn, 1817) & 36 & 1 & & & 3 & 6 & 23 & 3 & $\mathrm{RE}$ \\
\hline Modiolus capax (Conrad, 1837) & 30 & & 18 & 1 & & 1 & 10 & & $\mathrm{RE}$ \\
\hline Modiolus tumbezensis (Pilsbry \& Olsson, 1935) & 1 & & & & & & 1 & & $\mathrm{~L}$ \\
\hline \multicolumn{10}{|l|}{ ARCIDAE (3.05\%) } \\
\hline Acar gradata (Broderip \& Sowerby, 1829) & 8 & & 2 & & & 2 & 4 & & $\mathrm{RE}$ \\
\hline Acar pusilla (Sowerby I, 1833) & 2 & & 2 & & & & & & $\mathrm{~L}$ \\
\hline Acar rostae (Berry, 1954) & 8 & 8 & & & & & & & $\mathrm{~L}$ \\
\hline Arca mutabilis (Sowerby, 1833) & 4 & & 2 & & & & 2 & & $\mathrm{~L}$ \\
\hline Barbatia lurida (Sowerby, 1833) & 6 & 3 & 1 & & & & 2 & & $\mathrm{RE}$ \\
\hline Barbatia illota (Sowerby, 1833) & 3 & & & & & 1 & 2 & & $\mathrm{~L}$ \\
\hline Barbatia reeveana (d’Orbigny, 1846) & 5 & & & & 1 & & 4 & & $\mathrm{~L}$ \\
\hline \multicolumn{10}{|l|}{ PTERIIDAE (0.16\%) } \\
\hline Pinctada mazatlanica (Hanley, 1856) & 2 & & & & & & 2 & & $\mathrm{~L}$ \\
\hline \multicolumn{10}{|l|}{ ISOGNOMONIDAE (8.14\%) } \\
\hline Isognomon janus (Carpenter, 1857) & 96 & 16 & 27 & & & 20 & 6 & 27 & $\mathrm{RE}$ \\
\hline \multicolumn{10}{|l|}{ OSTREIDAE (17.82\%) } \\
\hline Saccostrea palmula (Carpenter, 1857) & 107 & 81 & 1 & & & & 25 & & $\mathrm{RE}$ \\
\hline Striostrea prismatica (Gray, 1824) & 103 & 82 & & & 5 & & 16 & & $\mathrm{RE}$ \\
\hline \multicolumn{10}{|l|}{ ANOMIIDAE (0.16\%) } \\
\hline Pododesmus foliatus (Broderip, 1834) & 2 & & 2 & & & & & & $\mathrm{~L}$ \\
\hline \multicolumn{10}{|l|}{ PLICATULIDAE (2.71\%) } \\
\hline Plicatula penicillata (Carpenter, 1857) & 18 & 4 & 4 & & & & 10 & & $\mathrm{RE}$ \\
\hline Plicatulostrea anomioides (Keen, 1958) & 14 & 3 & 4 & & & & 7 & & $\mathrm{RE}$ \\
\hline \multicolumn{10}{|l|}{ LIMIDAE (2.80\%) } \\
\hline Limaria pacifica (d’Orbigny, 1846) & 33 & 5 & 4 & 2 & & & 22 & & $\mathrm{RE}$ \\
\hline \multicolumn{10}{|l|}{ LUCINIDAE (0.08\%) } \\
\hline Ctena clarionensis (Hertlein \& Strong, 1946) & 1 & & & & & & 1 & & $\mathrm{~L}$ \\
\hline \multicolumn{10}{|l|}{ CARDITIDAE (6.70\%) } \\
\hline Cardites grayi (Dall, 1903) & 69 & 7 & 39 & 6 & 1 & 1 & 15 & & $\mathrm{~W}$ \\
\hline Cardites laticostatus (Sowerby, 1833) & 1 & & & & & & 1 & & $\mathrm{~L}$ \\
\hline Carditamera affinis (Sowerby, 1833) & 9 & & & 3 & & 2 & 4 & & $\mathrm{RE}$ \\
\hline \multicolumn{10}{|l|}{ CHAMIDAE (35.82\%) } \\
\hline Chama coralloides (Reeve, 1846) & 324 & 84 & 38 & 11 & 75 & 20 & 34 & 62 & $\mathrm{~W}$ \\
\hline Chama echinata (Broderip,1835) & 13 & & & & 3 & 1 & 9 & & $\mathrm{RE}$ \\
\hline Chama mexicana (Carpenter, 1857) & 51 & & & & 13 & 3 & 15 & 20 & $\mathrm{RE}$ \\
\hline Chama sordid (Broderip, 1835) & 34 & 6 & 25 & & 1 & & 2 & & $\mathrm{RE}$ \\
\hline \multicolumn{10}{|l|}{ PHOLADIDAE (0.08\%) } \\
\hline Martesia (Martesia) striata (Linnaeus, 1758) & 1 & & & & & & 1 & & $\mathrm{~L}$ \\
\hline Total abundance & 1178 & 302 & 175 & 29 & 106 & 71 & 220 & 275 & \\
\hline
\end{tabular}

$\mathrm{N}$ = number of organisms. Sites: A: Majahua, B: Tlacopanocha, C: Parque de la Reina, D: Muelle, E: La Angosta, F: Manzanillo, G: Pie de la Cuesta. $\mathrm{dt}=$ distribution type, $\mathrm{W}=$ broad, $\mathrm{RE}=$ regular, $\mathrm{L}=$ limited. 


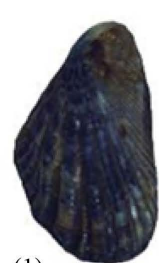

(1)

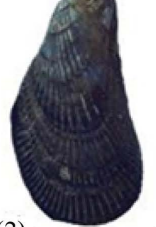

(2)

(3)

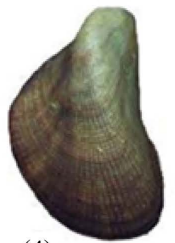

(4)
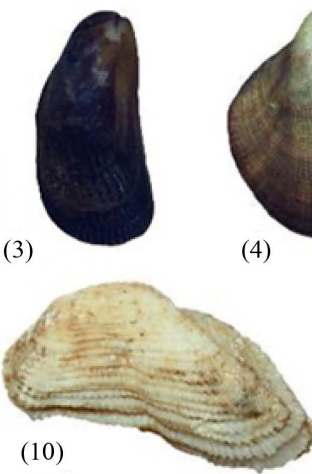

(5)

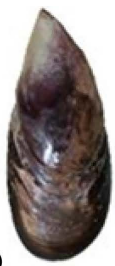

(6)

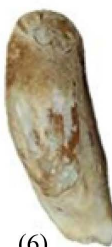

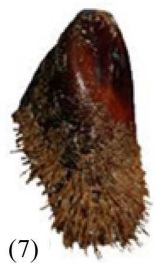

$(8) *$

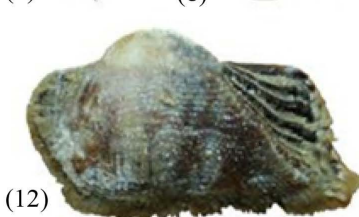

$(12)$
(9)

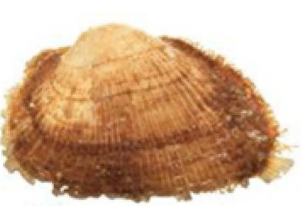

(13)

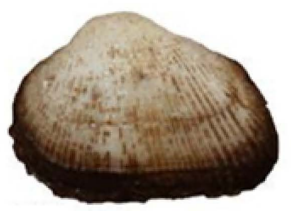

$(14)^{*}$

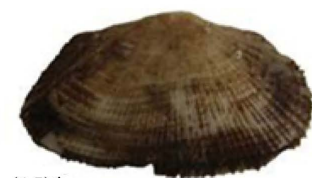

(15)*
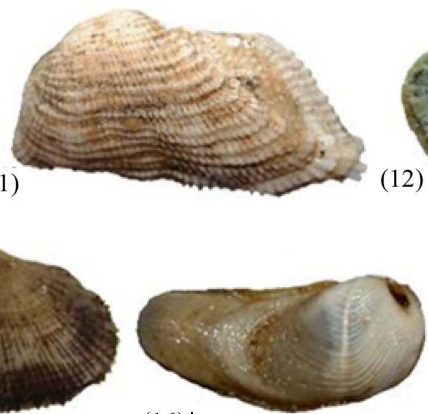

$(16)^{*}$

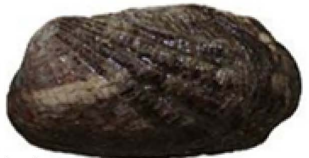

(17)

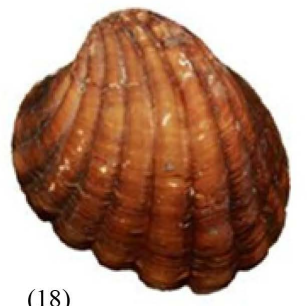

(18)
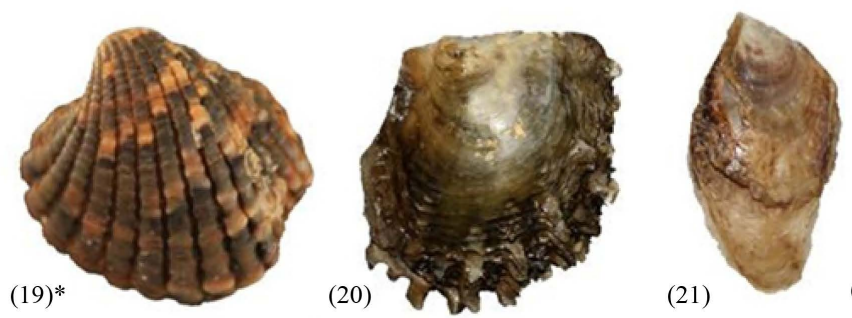

(21)

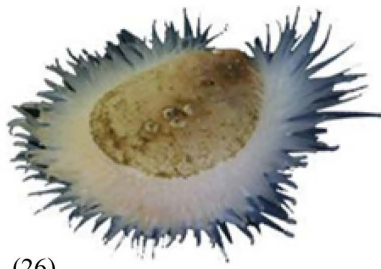

(26)
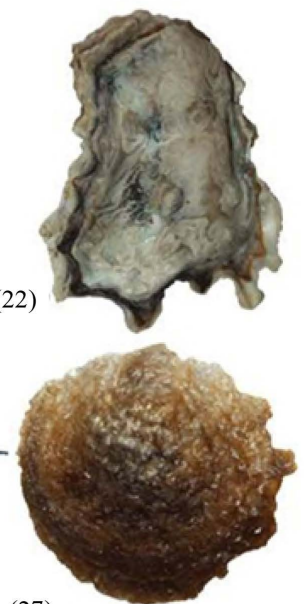

(27)

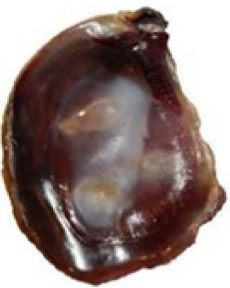

(31)

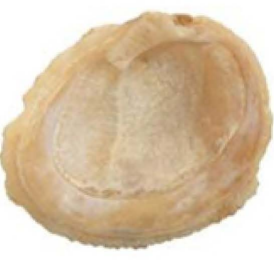

(32)

(1) Brachidontes adamsianus (2) B. puntarenensis (3) B. semilaevis (4) Septilifer zeteki (5) Choromytilus palliopunctatus (6) Lithophaga aristata (7) Modiolus capax (8) M. tumbezensis (9) Acar gradata (10) A. pusilla (11) A. rostae (12) Arca mutabilis (13) Barbatia Lurida (14) B. illota (15) B. reeveana (16) Martesia striata (17) Carditamera affinis (18) Cardites grayi (19) C. laticostatus (20) Pinctada mazatianica (21) Isognomon janus (22) Saccostrea palmula (23) Striostrea prismatica (24) Plicatula penicillata (25) Plicatulostrea anomioides (26) Lima pacifica (27) Pododesmus foliatus (28) Ctena clarionensis (29) Chama coralloides (30) C. echinata (31) C. mexicana (32) C. sordida.

(*) New records.

Pictures of the collection of marine invertebrates. Unidad Academica de Ecologia Marina. Universidad Autonoma de Guerrero. Photos: V.I. López-Rojas, C. Torreblanca-Ramirez, L. Galeana-Rebolledo y R. Flores-Garza.

Figure 2. Bivalve species associated with rocky intertidal zone of MPR 32, Acapulco, Mexico.

The species that showed the highest abundance in the rocky intertidal zone of the MPR 32 was Chama coralloides (Reeve, 1846) and represented $27.50 \%$ of the total abundance, followed by Choromytilus palliopunctatus (Carpenter, 1857) (12.81\%), Saccostrea palmula (Carpenter, 1857) (9.08\%) and Striostrea prismatica (Gray, 
1824) (8.74\%). These species together account for just over $58 \%$ relative abundance. The minimum value in abundance was presented at Modiolus tumbezensis (Pilsbry \& Olsson, 1935), Cardites laticostatus (Sowerby, 1833), Ctena clarionensis (Hertlein \& Strong, 1946) and M. (M.) striata.

C. coralloides was found to be the most abundant species in five sites (Majahua, Parque de la Reina, Muelle, La Angosta and Manzanillo). In the other two sites it ranked in second place in relative abundance. In Tlacopanocha, the species that had the highest abundance values was Cardites greyi (Dall, 1903). This species ranked second in abundance in Parque de la Reina. C. palliopunctatus was the most abundant species P. de la Cuesta (was only found on this site). In La Angosta, Isognomon janus (Carpenter, 1857), shared first place in abundance with C. coralloides (Table 3).

9.37\% of the species were found to have broad distribution, 56.22\% have regular distribution and $43.75 \%$ limited distribution. C. coralloides and Brachidontes adamsianus (Dunker, 1857) were present at all sites and C. grayi was presented at six sites (not found in Pie de la Cuesta). Ten species were found in one place, most of these species have very low values of relative abundances, however of these species C. palliopunctatus is found, recorded as the second in relative abundance in the MPR 32.

S. prismatica had the greatest average length, followed by B. reeveana and C. coralloides. S. palmula was registered the greatest average width, followed by Plicatulostrea anomioides (Keen, 1958). B. adamsianus and Brachidontes puntarenensis (Pilsbry \& Olsson, 1935), had the lowest average length, followed by Lithophaga (Myoforceps) aristata (Dillwyn, 1817) (Table 4).

The value of the diversity index of Shannon-Wiener $\left(\mathrm{H}^{\prime}\right)$ calculated for the MPR 32 was $\mathrm{H}^{\prime}=3.65$ bits/individuals and the value of Pielou index $\left(\mathrm{J}^{\prime}\right)$ was $\mathrm{J}^{\prime}=0.73$.

\section{Discussions and Conclusions}

In the area of the rocky coast of Michoacan, 19 species of bivalves were recorded [12]. This research is in

Table 3. Number of species, relative abundance and most abundant bivalve species associated with rocky intertidal sampling sites in MRP 32, Acapulco, Mexico.

\begin{tabular}{|c|c|c|c|c|c|}
\hline Site & NS & RA & Most abundant species & $\mathrm{n}$ & RAb-sp \\
\hline \multirow{3}{*}{ Majahua } & \multirow{3}{*}{13} & \multirow{3}{*}{25.6} & C. coralloides & 84 & 27.81 \\
\hline & & & S. prismatica & 82 & 27.15 \\
\hline & & & S. palmula & 81 & 26.82 \\
\hline \multirow{2}{*}{ Tlacopanocha } & \multirow{2}{*}{16} & \multirow{2}{*}{14.9} & C. greyi & 39 & 22.28 \\
\hline & & & C. coralloides & 38 & 21.71 \\
\hline \multirow[b]{2}{*}{ P. de la Reina } & \multirow[b]{2}{*}{7} & \multirow[b]{2}{*}{2.46} & C. coralloides & 11 & 37.93 \\
\hline & & & C. greyi & 6 & 20.68 \\
\hline \multirow[b]{2}{*}{ Muelle } & \multirow[b]{2}{*}{10} & \multirow[b]{2}{*}{8.99} & C. coralloides & 75 & 70.75 \\
\hline & & & C. mexicana & 13 & 12.26 \\
\hline \multirow{3}{*}{ La Angosta } & \multirow{3}{*}{13} & \multirow{3}{*}{6.02} & C. coralloides & 20 & 28.16 \\
\hline & & & & & \\
\hline & & & I. janus & 20 & 28.16 \\
\hline \multirow[b]{2}{*}{ Manzanillo } & \multirow[b]{2}{*}{25} & \multirow[b]{2}{*}{18.7} & C. coralloides & 34 & 15.45 \\
\hline & & & S. palmula & 25 & 11.36 \\
\hline \multirow[b]{2}{*}{ P. de la Cuesta } & \multirow[b]{2}{*}{7} & \multirow[b]{2}{*}{23.3} & C. palliopunctatus & 151 & 54.9 \\
\hline & & & & 62 & 254 \\
\hline
\end{tabular}

NS = number of species, RA = relative abundance $(\%), n=$ number of organisms per species, $\mathrm{RAb}$-sp = relative abundance of each species per site. 
Table 4. Length and width of the bivalve species associated with the rocky intertidal zone of MPR 32, Acapulco, Guerrero.

\begin{tabular}{|c|c|c|c|c|c|c|c|c|c|}
\hline \multirow{2}{*}{ Species } & \multicolumn{5}{|c|}{ Length (mm) } & \multicolumn{4}{|c|}{ Width (mm) } \\
\hline & $\mathrm{N}$ & Min & Avg & Max & SD & Min & Avg & Max & SD \\
\hline Brachidontes adamsianus & 21 & 2.2 & 3.5 & 6.7 & 1.2 & 21 & 3.6 & 5.7 & 10.6 \\
\hline Brachidontes puntarenensis & 21 & 2.4 & 3.5 & 7.9 & 1.1 & 21 & 2.1 & 5.9 & 8.6 \\
\hline Choromytilus palliopunctatus & 151 & 2.2 & 11.5 & 20.9 & 3.4 & 151 & 2.4 & 20.4 & 40.2 \\
\hline Lithophaga aristata & 36 & 0.9 & 3.7 & 30.9 & 5.8 & 36 & 1.5 & 5.0 & 10.3 \\
\hline Modiolus capax & 30 & 7.4 & 19.3 & 36.0 & 7.2 & 30 & 12.1 & 35.6 & 68.1 \\
\hline Acar gradata & 8 & 2.6 & 8.2 & 16.5 & 6.6 & 8 & 5.2 & 6.3 & 8.4 \\
\hline Acar rostae & 8 & 14.1 & 19.8 & 24.37 & 3.55 & 8 & 5.58 & 10 & 12.7 \\
\hline Arca mutabilis & 4 & 2.7 & 9.7 & 19.6 & 6.3 & 4 & 5.2 & 15.6 & 29.0 \\
\hline Barbatia lurida & 6 & 10.2 & 19.3 & 23.25 & 5.7 & 6 & 8.4 & 13 & 15.9 \\
\hline Barbatia illota & 3 & 7.5 & 13.1 & 21.3 & 7.2 & 3 & 4.8 & 9.0 & 15.4 \\
\hline Barbatia reeveana & 5 & 12 & 25.2 & 36.45 & 11.3 & 5 & 6.7 & 12.5 & 17.7 \\
\hline Isognomon janus & 96 & 3.5 & 8.6 & 17.0 & 2.8 & 96 & 4.8 & 10.9 & 30.2 \\
\hline Saccostrea palmula & 107 & 6.8 & 20.8 & 36.3 & 5.7 & 107 & 13.1 & 28.9 & 50.3 \\
\hline Striostrea prismatica & 103 & 12 & 36.7 & 82.5 & 20.8 & 103 & 8.3 & 35.1 & 84.6 \\
\hline Plicatula penicillata & 18 & 5.5 & 11.1 & 23.1 & 4.1 & 18 & 7.7 & 14.7 & 34.0 \\
\hline Plicatulostrea anomioides & 14 & 10 & 21.9 & 33.4 & 7.0 & 14 & 12.7 & 21.6 & 35.6 \\
\hline Lima pacifica & 33 & 4.3 & 10.4 & 19.2 & 3.5 & 33 & 8.2 & 17.2 & 30.9 \\
\hline Cardites grayi & 69 & 5.8 & 19.0 & 36.9 & 7.8 & 69 & 5.1 & 18.2 & 39.2 \\
\hline Carditamera affines & 9 & 3.7 & 18.0 & 31.2 & 8.2 & 9 & 6.7 & 9.9 & 12.9 \\
\hline Chama coralloides & 324 & 3.4 & 25.0 & 65.4 & 12.8 & 324 & 6.1 & 25.4 & 54.9 \\
\hline Chama echinata & 13 & 7.2 & 19.9 & 40.3 & 9.5 & 13 & 7.4 & 24.3 & 48.5 \\
\hline Chama mexicana & 51 & 2.4 & 13.2 & 36.1 & 6.7 & 51 & 3.0 & 15.4 & 54.2 \\
\hline Chama sordida & 34 & 7.3 & 18.4 & 58.9 & 9.4 & 34 & 9.4 & 20.0 & 44.5 \\
\hline
\end{tabular}

$\mathrm{N}=$ number of specimens measured, Min = minimum, $\mathrm{M}=$ average, $\mathrm{Max}=$ maximum, $\mathrm{SD}=$ standard deviation.

agreement with six of the species reported in Michoacan: they are Brachidontes semilaevis (Menke, 1848), C. palliopunctatus, Modiolus capax (Conrad, 1837), Pinctada mazatlanica (Hanley, 1856), Chama mexicana (Carpenter, 1857) and Limaria pacifica (d'Orbigny, 1846). [21] reported 24 species of bivalves in the rocky intertidal zone of Navachiste islands in Sinaloa. Our results are in agreement with the findings of I. janus, S. palmula, C. grayi and C. laticostata [40], who reported 11 species of bivalves in the coral reef of Tenacatita, Jalisco, of which this research found Acar gradata (Broderip \& Sowerby), B. adamsianus, M. capax, P. mazatlanica, Carditamera affines (Sowerby, 1833), and Chama sordida (Broderip, 1835) in the study area. Study of bivalve community in the Mazatlan Bay [24] reported 26 families and 89 species; the work was carried out in two areas of intertidal and shallow subtidal sandy and rocky sites. This research found 10 families and 21 species similar to those reported in Mazatlan.

In research carried out in the state of Guerrero, [15] in Zihuatanejo, recorded 37 species of Class Bivalvia. The research was conducted in sandy and rocky sites, in the intertidal and subtidal zones. This study is in agreement with the report in which 14 species are cited including A. gradata, Acar rostae (Berry 1954), Arca mutabilis (Sowerby, 1833), B. reeveana, B. semilaevis, Septifer zeteki (Hertlein \& Strong, 1946), L. aristata, M. capax, P. mazatlanica, I. janus, L. pacifica, C. affines, Chama echinata (Broderip, 1835) and C. mexicana. [14] reported nine species of the Class Bivalvia for the rocky intertidal zone of the State of Guerrero, which agree with our findings: A. mutabilis, B. semilaevis, C. palliopunctatus, S. palmula, S. prismatica, I. janus, C. affinis 
and C. echinata.

In reports regarding Acapulco, [31] recorded 11 species of the Class Bivalvia; [30] recorded 13 bivalves; [32] reported nine species; [33], eight species and [34] recorded 21 species. Our findings agree with those of the authors mentioned above regarding all species, except the report on Pseudochama inermis (Dall, 1871).

In this study, four new records for the Mexican Pacific Transitional are reported: one for the state of Guerrero and one for the MPR 32 (Table 5).

This research provides important information about the Class Bivalvia in the rocky intertidal zone of the MRP 32 where CONABIO noted the lack of information on marine diversity.

The Class Bivalvia is well represented in the rocky intertidal zone of the MRP 32; the above is verified by species richness found. This research reports the highest value in bivalve species richness associated with the rocky intertidal zone of the state of Guerrero.

The differences in observed species richness compared to other research conducted in the rocky intertidal zone of the state of Guerrero, are attributed to greater sampling effort, easy access to the sites, a meticulous review of the area and variability features of the substrate sites, the set of sampled sites, and represent the entire variety of substrate types that make up the rocky intertidal zone of the MPR 32 and this research sampling efforts focused on the Class Bivalvia.

The number of known species in the study area has increased.

The species richness found, corresponds to that expected in the rocky intertidal zone located in a tropical zone, which is comprised of sites that have various types of rocky substrates, and are different in wave exposure.

In the study area, Families Chamidae, Arcidae and Mylitidae have been reported as the best represented in species richness [30]-[34]. This research found the same result.

The greatest species richness was found at sites with medium or low stability of the substrate, formed by blocks of rock, boulders or gravel and protected from direct wave impact. Sites with lower species richness have substrate with a high degree of stability and the impact of the waves is direct on the substrate. [41] reported that there is a direct correlation between the stability of the beaches and the type of species and [42] found greater species richness in sites that are substrates of pebbles compared to sites with firm substrate such as cliffs. [14] analyzing the biodiversity of mollusks distributed in nine sites on the coast of the State of Guerrero, reported that species richness is associated with habitat stability and wave intensity at each site. Unstable sites, formed by boulders and with less intensity wave, had higher species richness. Sites with stable substrates and greater wave exposure had lower species richness.

New records of species of bivalves are reported, which show that much remains to be learned about marine fauna resources for the state of Guerrero, hence the importance in conducting research for marine fauna.

Mytilidae and Chamidae Families had the best representation in abundance. Similar results are reported by [24], in Mazatlán Bay and [32]-[34], to Acapulco.

The Chamidae, Arcidae and Mytilidae Families turned out to be better represented in species richness, abundance and distribution which are considered as the representative families of MPR 32.

Lucinidae, Pholadidae, Anomiidae and Pteridae Families are considered rare in the rocky intertidal zone of the MPR 32.

C. coralloides, has been reported as the longest species in the MPR 32 [31]-[34]. C. sordida and C. grayi are also reported by the majority of the research as representative or dominant. This research also found these species as dominant.

For values of abundance and distribution, C. coralloides was considered to be the representative species of the rocky intertidal zone of the MPR 32, and also can be considered representative of this area-S. palmula, $S$. prismática and C. greyi, with the exception of sites whose substrate is entirely exposed to the impact of the waves as in Pie de la Cuesta. Also B. adamsianus for its distribution (found everywhere) is considered to be representative of the area. It was determined that $C$. pallopunctatus is a highly specialized species and represents the highest energy sites in the MPR 32.

On the low values of abundance and limited distribution, Acar pusilla (Sowerby I, 1833), B. semilaevis, S. zeteki, M. tumbezensis, P. mazatlanica, Pododesmus foliates (Broderip, 1834), C. laticostatus, C. clarionensi and M. striata are considered rare species in the rocky intertidal zone of MPR 32.

C. coralloides, has been reported as the species with the larger MPR 32 [32]-[34]. In this research, S. prismática recorded the greatest size; however $C$. coralloides is recorded having the greatest length among the species. 
Table 5. New records in the Mexican Pacific Transitional, the state of Guerrero and the Marine Priority Region No. 32.

\begin{tabular}{|c|c|c|c|c|c|c|c|}
\hline \multirow{2}{*}{ Family/Species } & \multirow{2}{*}{$\mathrm{N}$} & \multicolumn{4}{|c|}{ Long (mm) } & \multirow{2}{*}{ Known Distribution } & \multirow{2}{*}{ New Distribution } \\
\hline & & Min & Avg & Max & SD & & \\
\hline \multicolumn{8}{|c|}{ Mexican Pacific Transitional } \\
\hline $\begin{array}{l}\text { ARCIDAE } \\
\text { J. E. Gray, } 1854 \\
\text { Barbatia illota } \\
\text { (Sowerby, 1833) }\end{array}$ & 3 & 7.5 & 13.1 & 21.3 & 7.2 & $\begin{array}{l}\text { Mexico: Gulf of California (Isla Angel de la Guarda, } \\
\text { Puertecitos and San Felipe), Baja California Sur } \\
\text { (Concepcion Bay), Sonora (Puerto Peñasco), Nayarit } \\
\text { (San Blas) and Sinaloa (Mazatlan Bay). In an Island } \\
\text { of Honduras. Panama: Coiba Island, Hato Island, } \\
\text { Bays of Panama and Venado. Colombia. Ecuador: } \\
\text { GalapagosIslands and Salinas. Peru: Lobitos. Brazil: } \\
\text { Balneario of Camboriu, Nearitajai, Santa Catarina. } \\
\text { (Keen, 1971, Skoglund, 2001, World Register of } \\
\text { Marine Species, WMSDB-Worldwide Mollusk } \\
\text { Species Data Base, DISCOVER LIFE and } \\
\text { Ezqueda-Gonzáles et al., 2014). }\end{array}$ & $\begin{array}{l}\text { Manzanillo } \\
16^{\circ} 50^{\prime} 27.90 " \mathrm{~N}, \\
99^{\circ} 54^{\prime} 38.14^{\prime \prime} \mathrm{W} \\
\text { La Angosta } \\
16^{\circ} 47^{\prime} 39.62^{\prime \prime} \mathrm{N} \\
99^{\circ} 50^{\prime} 29.02^{\prime \prime} \mathrm{W}\end{array}$ \\
\hline $\begin{array}{c}\text { MYTILIDAE } \\
\text { Rafinesque, } 1815 \\
\text { Modiolus tumbezensis } \\
\text { (Pilsbry \& Olsson, 1935) }\end{array}$ & 1 & 6.1 & & & & $\begin{array}{l}\text { Mexico (Nayarit). } \\
\text { (Reguero y García-Cubas, } 1988 \text { and World Register } \\
\text { of Marine Species). }\end{array}$ & $\begin{array}{l}\text { Manzanillo } \\
16^{\circ} 50^{\prime} 27.90^{\prime \prime} \mathrm{N} \\
99^{\circ} 54^{\prime} 38.14^{\prime \prime} \mathrm{W}\end{array}$ \\
\hline $\begin{array}{l}\text { LUCINIDAE } \\
\text { J. Fliming, } 1828\end{array}$ & 1 & 9.7 & & & & \multirow{2}{*}{$\begin{array}{l}\text { Mexico: On the West Coast, Clarion Island, Gulf of } \\
\text { California, Rocas Alijos Rocks, San Carlos Bay, } \\
\text { Sonora); Costa Rica: Cocos Island. Ecuador: } \\
\text { Galapagos Islands. } \\
\text { (Keen, 1971, Skoglund, 2001, World Register of } \\
\text { Marine Species and WMSDB-Worldwide Mollusc } \\
\text { Species Data Base). }\end{array}$} & \\
\hline $\begin{array}{c}\text { Ctena clarionensis } \\
\text { (Hertlein \& Strong, 1946) }\end{array}$ & & & & & & & $99^{\circ} 54^{\prime} 38.14^{\prime \prime} \mathrm{W}$ \\
\hline $\begin{array}{l}\text { PHOLADIDAE } \\
\text { Lamarck, } 1809 \\
\text { Martesia }(M) \text { striata } \\
\text { (Linnaeus, 1758) }\end{array}$ & 1 & 13.7 & & & & $\begin{array}{l}\text { Mexico: On the Shores of the Pacific (Baja California } \\
\text { and Sonora), Caribbean Sea, Gulf of Mexico. Costa } \\
\text { Rica. Cuba. Puerto Rico. Tasmania. Lesser Antilles. } \\
\text { United Kingdom. South Africa. Thailand and East } \\
\text { China Sea. (Keen, 1971, Skoglund, } 2001 \text { and World } \\
\text { Register of Marine Species and DISCOVER LIFE). }\end{array}$ & $\begin{array}{l}\text { Manzanillo } \\
16^{\circ} 50^{\prime} 27.90^{\prime \prime} \mathrm{N} \\
99^{\circ} 54^{\prime} 38.14^{\prime \prime} \mathrm{W}\end{array}$ \\
\hline \multicolumn{8}{|c|}{ State of Guerrero } \\
\hline $\begin{array}{l}\text { CARDITIDAE } \\
\text { Férussac, } 1822 \\
\text { Cardites laticostatus } \\
\text { (Sowerby I, 1833) }\end{array}$ & 1 & 16.7 & & & & $\begin{array}{l}\text { Mexico: Sinaloa (NavachisteIslands), Colima } \\
\text { (Revillagigedo Islands); El Salvador. Panama } \\
\text { (Panama Bay, Governor Island, CebacoIslands Puna } \\
\text { Island, Gulf of Montijo and Venado Islands); Costa } \\
\text { Rica (Cocos Island); Ecuador (Galapagos Islands). } \\
\text { (Skoglund, 2001, Keen, 1971, Ortiz-Arellano and } \\
\text { Flores-Campaña 2008, WMSDB-Worldwide } \\
\text { Mollusc Species Data Base and DISCOVER LIFE). }\end{array}$ & $\begin{array}{l}\text { Manzanillo } \\
16^{\circ} 50^{\prime} 27.90^{\prime \prime} \mathrm{N} \\
99^{\circ} 54^{\prime} 38.14^{\prime \prime} \mathrm{W}\end{array}$ \\
\hline \multicolumn{8}{|c|}{ Marine Priority Region 32} \\
\hline $\begin{array}{l}\text { ARCIDAE } \\
\text { J. E. Gray, } 1854 \\
\text { Barbatia }(C) \text { reeveana } \\
\text { (d‘Orbigny, } 1846)\end{array}$ & 5 & 11.99 & 25.20 & 36.45 & 11.31 & $\begin{array}{l}\text { Mexico: Rocas Alijos, Gulf of California } \\
\text { (Puertecitos), Baja California Sur (Bahía } \\
\text { Concepción) and Guerrero (La barrita and } \\
\text { Zihuatanejo). Panama. Costa Rica (Cocos Island). } \\
\text { Colombia (Mal Pelo Islands). Ecuador } \\
\text { (GalapagosIslands) and Peru (South of lobitos). } \\
\text { (Salcedo et al., 1988, World Register of Marine } \\
\text { Species, WMSDB-Worldwide Mollusc Species } \\
\text { Data Base and DISCOVERI LIFE). }\end{array}$ & $\begin{array}{c}\text { Manzanillo } \\
16^{\circ} 50^{\prime} 27.90^{\prime \prime} \mathrm{N}, \\
99^{\circ} 54^{\prime} 38.14^{\prime \prime} \mathrm{W} \\
\text { Muelle } \\
16^{\circ} 50^{\prime} 58.27^{\prime \prime} \mathrm{N}, \\
99^{\circ} 54^{\prime} 01.85^{\prime \prime} \mathrm{W}\end{array}$ \\
\hline
\end{tabular}

$\mathrm{N}=$ number of specimens tested, $\mathrm{Min}=$ minimum, $\mathrm{Avg}=$ average, $\mathrm{Max}=$ maximum, $\mathrm{SD}=$ standard deviation .

B. adamsianus has been reported as the smallest species in the MPR 32 [33] [34], also L. (M) aristata [32]. This research also found these species as among those with the smallest recorded length.

The values of diversity and equity for mollusks, which have been reported by other research conducted at sites that are located in the MPR 32 [33] [34] are high. We also found high values, which correspond to a tropical area. 
The high values of diversity and uniformity found in the study area indicate that the studied region is a highly diverse area and corresponds to well-established benthic ecosystems, which have very stable environmental conditions.

\section{References}

[1] Wilkinson, T., Wiken, E., Bezaury, C.J., Hourigan, T., Agardy, T., Herrmann, H., Janishevski, L., Madden C., Morgan, L. and Padilla, M. (2009) Ecorregiones marinas de América del Norte. Comisiónpara la Cooperación Ambiental, Montreal.

[2] Carranza-Edwars, A., Gutiérrez-Estrada, M. and Rodríguez-Torres, R. (1975) Unidades morfo-tectónicas continentales de las costas mexicanas. Anales del Instituto de Ciencias del Mar y Limnología. Universidad Nacional Autónoma de México, 2, 81-88.

[3] Arriaga, C.L., Aguilar, V. and Espinoza, J.M. (1998) Regiones prioritarias de México. Comisión nacional para el conocimiento y uso de la biodiversidad. CONABIO, México.

[4] Maeda-Martínez, A.N. (2008) Estado actual del cultivo de Bivalvos en Mexico. http://www.fao.org/3/a-i0444s/i0444s06.pdf

[5] Baqueiro, E. and Stuardo, J. (1977) Observaciones sobre la biología, ecología y explotación de Megapitaria aurantiaca (Sowerby, 1831), Megapitaria squalida (Sowerby, 1835) y Dosinia ponderosa (Gray, 1838) (Bivalvia: Veneridae) de la bahía de Zihuatanejo e isla Ixtapa, Guerrero, México. Anales del Centro de Ciencias del Mar y Limnología. Universidad Nacional Autónoma de México, 4, 161-208.

[6] Baqueiro and Aldana, D. (2003) Patrones en la biología poblacional de moluscos de importancia comercial en México. Revista Biológica Tropical, 51, 97-117.

[7] Holguín, O. and González, A.C. (1989) Moluscos de la franja costera del Estado de Oaxaca, México, Dirección de Bibliotecas y Publicaciones. Instituto Politécnico Nacional, México.

[8] Reguero, M. and García-Cubas, A. (1988) Moluscos de la plataforma continental de Nayarit: Sistemática y ecología (cuatro campañas oceanográficas). Anales del Centro de Ciencias del Mar y Limnología. Universidad Nacional Autónoma de México, 16, 33-58.

[9] Holguín-Quiñones, O.E. and González-Pedraza, A.C. (1994) Moluscos de la franja costera de Michoacán, Colima y Jalisco, México, Dirección de Bibliotecas y Publicaciones. Instituto Politécnico Nacional, México.

[10] Landa-Jaime, V. and Arciniega-Flores, J. (1998) Macromoluscos bentónicos de fondos blandos de la plataforma continental de Jalisco y Colima, México. Ciencias Marinas, 24, 155-167.

[11] León-Herrera, M. (2000) Listado taxonómico de las especies de moluscos en la zona central del litoral Oaxaqueño. Ciencia y Mar, 12, 49-51.

[12] Villarroel, M.M., Magaña, A., Gómez, B., Del Río, O., Lucio, J. and Sánchez, J. (2000) Diversidad de moluscos en el litoral rocoso de Michoacán, México. Mexicoa, 2, 54-63.

[13] Landa-Jaime, V., Cruz-Urzua, M., Michel-Morfín, J.E., Arciniega-Flores, J., Flores-Vargas, R. and Amezcua, C. (2007) Guía ilustrada para la identificación de moluscos intermareales y de arrecifes en la Bahía de Tenacatita, Jalisco. In: Ríos-Jara, E., Esqueda-González, M.C. and Galván-Villas, C.M., Eds., Estudios sobre la Malacología y Conquiliología en México, Universidad de Guadalajara, Guadalajara, 63-64.

[14] Flores-Rodríguez, P., Flores-Garza, R., García-Ibáñez, S., Valdés-González, A., Violante-González, J., Santiago Cortés, E., Galeana-Rebolledo, L. and Torreblanca-Ramírez, C. (2012) Mollusk Species Richness on the Rocky Shores of the State of Guerrero, Mexico, as Affected by Rains and Their Geographical Distribution. Natural Resources, 3, 248-260. http://dx.doi.org/10.4236/nr.2012.34032

[15] Salcedo, M.S., Green, G., Gamboa, A. and Gómez, P. (1988) Inventario de macroalgas y macroinvertebrados bénticos, presentes en áreas rocosas de la región de Zihuatanejo, Guerrero, México. Anales del Centro de Ciencias del Mar y Limnología, 15, 73-96.

[16] Román, R., Cruz, F. and Ibáñez, A.L. (1991) Observaciones ecológicas de los moluscos de la zona intermareal de la bahía de Chamela, Jalisco, México. Anales del Instituto de Biología, 62, 17-32.

[17] Esqueda, M.C., Ríos-Jara, E., Michel-Morfín, J.E. and Landa-Jaime, V. (2000) The Vertical Distribution and Abundance of Gastropods and Bivalves from Rocky Beaches of Cuastecomate Bay, Jalisco. Revista de Biología Tropical, 48, 765-775. http://www.scielo.sa.cr/scielo.php?script=sci_arttext\&pid=S0034-77442000000400004

[18] Flores, R.P. (2004) Estructura de la comunidad de moluscos del mesolitoral superior en las playas de facie rocosa del estado de Guerrero, México. Tesis de Doctorado, Facultad de Ciencias Biológicas, Universidad Autónoma de Nuevo León, Nuevo León.

[19] Flores-Garza, R., Flores-Rodríguez, P., García-Ibáñez, S. and Valdés-González, A. (2007) Demografía del caracol 
Plicopurpura pansa (Neotaenioglossa: Muricidae) y constitución de la comunidad malacológica asociada en Guerrero, México. Revista de Biología Tropical, 55, 867-887.

http://www.scielo.sa.cr/scielo.php?pid=S0034-77442007000300012\&script=sci_arttext http://dx.doi.org/10.15517/rbt.v55i3-4.5962

[20] Flores-Rodríguez, P., Flores-Garza, R., García-Ibáñez, S. and Valdés-González, A. (2007) Variación en la diversidad malacológica del mesolitoral rocoso en Playa Troncones La Unión, Guerrero, México. Revista Mexicana de Biodiversidad, 78, 33S-40S. http://www.ejournal.unam.mx/bio/BIOD78-02S/BIO0780S0205.pdf

[21] Ortiz-Arellano, M.A. and Flores-Campaña, L.M. (2008) Catálogo descriptivo e ilustrado de los moluscos de la zona intermareal de las islas de Navachiste, Sinaloa, México. Universidad Autónoma de Sinaloa y Gobierno del Estado de Sinaloa-Consejo Nacional de Ciencias y Tecnología, México.

[22] Zamorano, P., Barrientos-Luján, N. and Ramírez-Luna, S. (2008) Malacofauna del infralitoral rocoso de Agua Blanca, Santa Elena Cozoaltepec, Oaxaca. Ciencia y Mar, 12, 19-33. http://www.umar.mx/revistas/36/malacofauna.pdf

[23] Flores-Rodríguez, P., Barba-Marino, F., Flores-Garza, R., García-Ibáñez, S. and Arana-Salvador, D.G. (2010) Análisis de la comunidad de moluscos del mesolitoral rocoso en playa Corralero, Oaxaca, México. In: Rangel, L., Gamboa, J., Arriaga, W. and Contreras, W.M., Eds., Perspectiva en Malacología Mexicana, Universidad Juárez Autónoma de Tabasco, Tabasco, 79-87.

[24] Esqueda-González, M.C., Ríos-Jara, E., Galván-Villa, C. and Rodríguez-Zaragoza, F.A. (2014) Species Composition, Richness, and Distribution of Marine Bivalve Molluscs in Bahía de Mazatlán, México. ZooKeys, 399, 43-69. http://dx.doi.org/10.3897/zookeys.399.6256

[25] Villalpando, E. (1986) Diversidad y zonación de moluscos de superficie rocosa, Isla Roqueta, Acapulco, Guerrero. Tesis de Licenciatura, Universidad Nacional Autónoma de México, México.

[26] García, J.A. (1994) Fauna malacológica de acompañamiento del caracol Purpura pansa (Gould 1853) en la zona mesolitoral de la isla Roqueta, Acapulco, Guerrero, México. Tesis de Licenciatura, Universidad Autónoma de Guerrero, Chilpancingo.

[27] Flores-Rodríguez, P., Flores-Garza, R., García-Ibáñez, S. and Valdés-González, A. (2003) Riqueza y diversidad de la malacofauna del mesolitoral rocoso de la Isla la Roqueta, Acapulco, Guerrero, México. Ciencia Revista de Investigación Científica, 2, 5-14.

[28] Valdés-González, A., Flores-Rodríguez, P., Flores-Garza, R. and García-Ibáñez, S. (2004) Molluscan Communities of Rocky Intertidal Zone at Two Sites with Different Wave Action on Isla la Roqueta, Acapulco, Guerrero, México. Journal of Shellfish Research, 23, 875-880.

[29] Barba-Marino, F., Flores-Rodríguez, P., Flores-Garza, R., García-Ibáñez, S. and Arana-Salvador, D.G. (2010) Biodiversidad y zonificación de la comunidad de moluscos, que habita el sustrato rocoso en dos sitios con distinta acción del oleaje, en la Isla "La Roqueta”, Acapulco, Guerrero, México. In: Rangel, L., Gamboa, J., Arriaga, W. and Brusca, R.C., Eds., Perspectiva en Malacología Mexicana, Universidad Juárez Autónoma de Tabasco, Tabasco, 21-43.

[30] Torreblanca, R.C. (2010) Análisis de la diversidad y estructura de la comunidad de moluscos del mesolitoral rocoso de Acapulco, Gro. Tesis de Licenciatura, Unidad Académica de Ecología Marina, Universidad Autónoma de Guerrero, Chilpancingo.

[31] Flores-Garza, R., Torreblanca-Ramírez, C., Flores-Rodríguez, P., García-Ibáñez, S. and Galeana-Rebolledo, L. (2010) Riqueza y Análisis de la comunidad malacológica en el mesolitoral rocoso de la playa Tlacopanocha, Acapulco, Guerrero. In: Rangel, L., Gamboa, J., Arriaga, W. and Contreras, W.M., Eds., Perspectiva en Malacología Mexicana, Universidad Juárez Autónoma de Tabasco, Tabasco, 125-138.

[32] Flores-Garza, R., Torreblanca-Ramírez, C., Flores-Rodríguez, P., García-Ibáñez, S., Galeana-Rebolledo, L., ValdésGonzález, A. and Rojas-Herrera, A.A. (2011) Mollusc Community from a Rocky Intertidal Zone in Acapulco, México. Biodiversity, 12, 144-153. http://dx.doi.org/10.1080/14888386.2011.625520

[33] Torreblanca-Ramírez, C., Flores-Garza, R., Flores-Rodríguez, P., García-Ibáñez, S. and Galeana-Rebolledo, L. (2012) Riqueza, composición y diversidad de la comunidad de moluscos asociada al sustrato rocoso intermareal de playa Parque de la Reina, Acapulco, México. Revista de Biología Marina y Oceanografía, 47, 283-294. http://dx.doi.org/10.4067/S0718-19572012000200010

[34] Galeana-Rebolledo, L., Flores-Garza, R., Torreblanca-Ramírez, C., García-Ibáñez, S., Flores-Rodríguez, P. and LópezRojas, V. (2012) Biocenosis de Bivalvia y Polyplacophora del intermareal rocoso en playa Tlacopanocha, Acapulco, Guerrero, México. Latin American Journal of Aquatic Research, 40, 943-954. http://dx.doi.org/10.3856/vol40-issue4-fulltext-11

[35] Mottana, A., Crespi, R. and Liborio, G. (1980) Guía de minerales y rocas. Segunda edición, Grijalbo, Barcelona.

[36] Flores-Garza, R., Galeana-Rebolledo, L., Reyes-Gómez, A., García-Ibáñez, S., Torreblanca-Ramirez, C., Flores-Rodríguez, P. and Valdés-González, A. (2012) Polyplacophora Species Richness, Composition and Distribution of Its Community Associated with the Intertidal Rocky Substrate in the Marine Priority Region No. 32 in Guerrero, Mexico. Open Jour- 
nal of Ecology, 2, 192-201.

[37] Keen, A.M. (1971) Sea Shells of Tropical West America. Stanford University Press, Palo Alto.

[38] Skoglund, K. (2001) Additions to the Panamic Province Bivalve (Mollusca) Literature 1971 to 2000. The Festivus, 32.

[39] Coan, E.V. and Valentich-Scott, P. (2012) Bivalve Seashells of Tropical West America. Marine Bivalve Mollusks from Baja California to Peru. Santa Barbara Museum of Natural History Monographs, EUA.

[40] Rodríguez, M. (2007) Guía ilustrada para la identificación de Moluscos intermareales y de arrecife de playa Mora, Tenacatita, Jalisco. Tesis de Licenciatura, Universidad de Guadalajara, Guadalajara.

[41] Brusca, R.C. (1980) Common Intertidal Invertebrates of the Gulf of California. University of Arizona Press, Tucson.

[42] Spight, T.M. (1977) Diversity of Shallow-Water Gastropods Communities on Temperature and Tropical Beaches. American Naturalist, 111, 1077-1097. http://dx.doi.org/10.1086/283239 
Scientific Research Publishing (SCIRP) is one of the largest Open Access journal publishers. It is currently publishing more than 200 open access, online, peer-reviewed journals covering a wide range of academic disciplines. SCIRP serves the worldwide academic communities and contributes to the progress and application of science with its publication.

Other selected journals from SCIRP are listed as below. Submit your manuscript to us via either submit@scirp.org or Online Submission Portal.
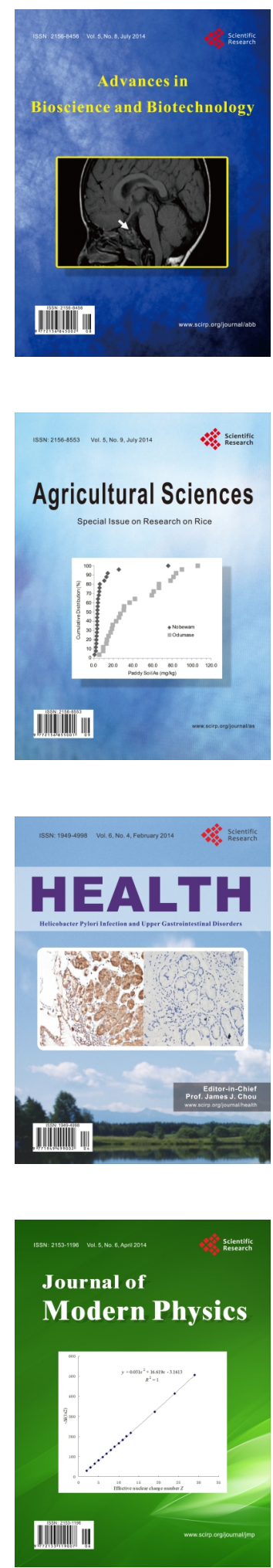
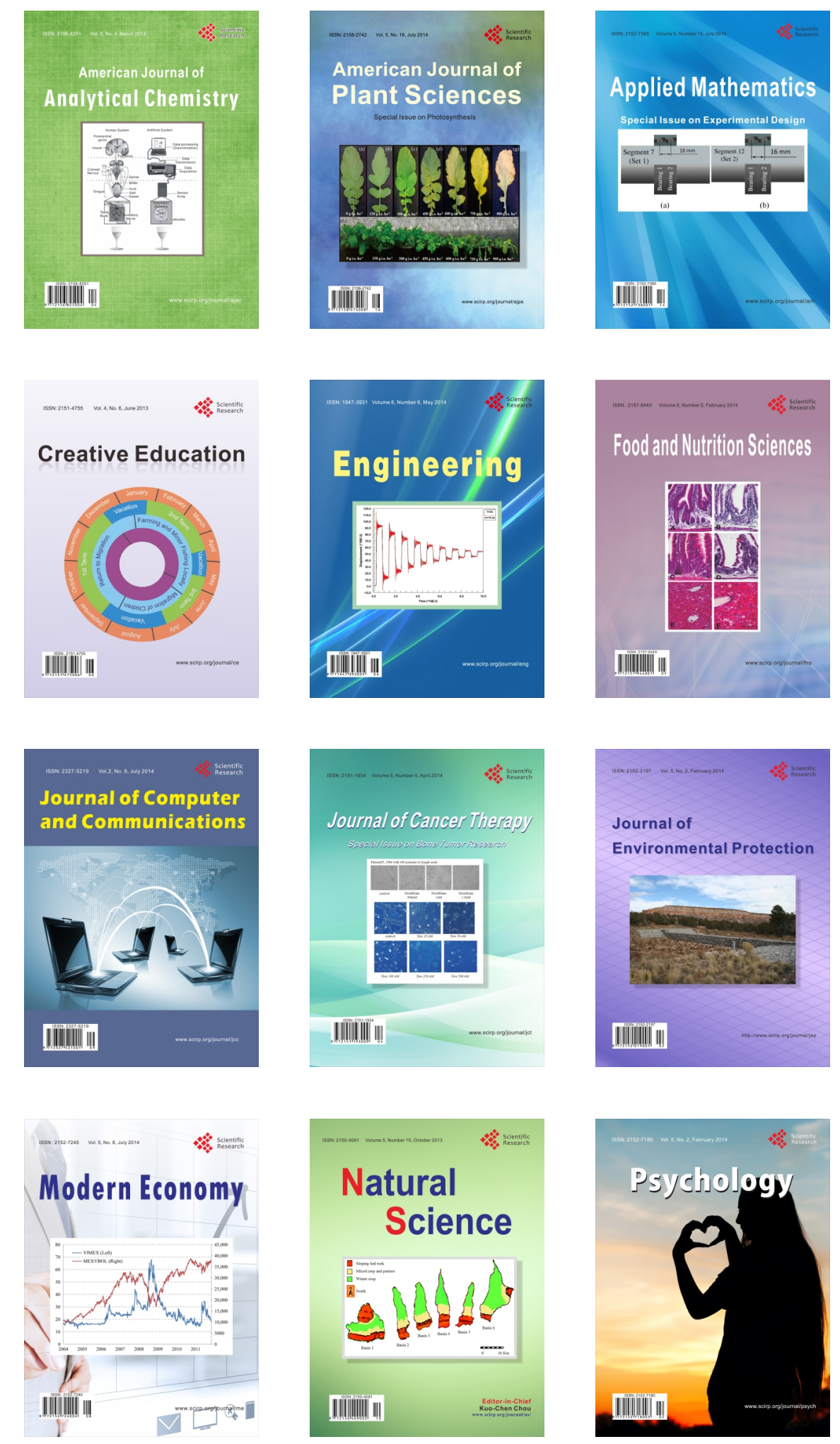